\title{
MULTIPLE THREE-WAWE RESONANCES IN TWO-STREAM FREE- ELECTRON LASER WITH A HELICAL ELECTRON BEAM
}

\author{
O.V.Lysenko, J.J.Volk, A.S.Serozhko \\ Sumy State University, Sumy, Ukraine \\ O.O.Rybalko \\ Danish Technical University, Congres Longbury, Denmark
}

Background. A powerful terahertz radiation sources creation is one of the perspective tendencies in relativistic plasma electronics. Nowadays there are few devices able to create powerful radiation in millimeter-infrared waveband (even in the part of this band). Therefore, theoretical research of novel powerful terahertz radiation sources, that are also characterized by broad frequency spectrum, is an actual problem.

Objective. The aim of the paper is a study of the influence of multiple three-wave resonant interactions in the klystron type two-stream superheterodyne free-electron laser (TSFEL) with helical electron beam on the forming effectiveness of the powerful waves with broad frequency spectrum.

Methods. In order to theoretically analyze multiple resonances of wave harmonics, as initial, we use quasihydrodynamic equation, the continuity equation and Maxwell's equations. We apply the hierarchic approach to the theory of oscillations and waves to the equations of motion and continuity, Maxwell's equations are solved by means of the slowly varying amplitude method. As a result, we derive a system of differential equations for complex amplitudes of SCW electric field strength harmonics which we analyze by standard methods.

Results. It was shown that in the two-stream superheterodyne FELs, utilizing the two-stream instability in helical electron beams as an additional electromagnetic wave amplification mechanism, the powerful multiharmonic space charge wave with broad frequency spectrum forms due to multiple resonant interactions. The spectrum width of such wave is larger compared to the spectrum width in TSFELs utilizing straight electron beams. It is also found out that amplification rates in such TSFELs are higher.

Conclusions. An application of helical electron beams in multiharmonic TSFELs using multiple resonant interactions leads to the improvement of their amplification characteristics, frequency spectrum widening in multiharmonic signal generation mode, and to overall geometric dimensions decreasing compared to TSFELs utilizing straight beams.

Keywords: two-stream superheterodyne free-electron laser; two-stream instability; helical electron beams; three-wave resonances.

\section{Introduction}

Two-Stream Superheterodyne Free Electron Laser

As you know, TSFEL [1-7] are characterized by a number of unique properties that make them quite promising for various practical applications. One of the main advantages of TSFEL is their particular compactness and ability to operate in extremely high gain modes, the ability to form a powerful multiharmonic electromagnetic signal with a wide frequency spectrum [1-5]. This is ensured by the effect of superheterodyne amplification of electromagnetic waves in the plasma of relativistic electron beams [1-3]. The idea of this effect is to use the own instability of a beam of various types (including longitudinal electron waves) to amplify the transverse electromagnetic wave of a signal [1-3]. The parametric interaction mechanism, which is fundamental to conventional free electron lasers (FEL), is used here only to transform the amplification from longitudinal electron waves into the amplification of transverse electromagnetic waves. We also note that waves which are amplified by instability are characterized by the linear dispersion dependence [1-9]. Due to this property, the harmonics of such waves appear to be connected with each other by the large number of three-wave parametric resonances $[1,3-5,8]$. This leads to intense excitation of higher harmonics, which, moreover, are amplified due to their own instability. As a result, such systems can be sources of powerful multiharmonic electromagnetic waves with a wide frequency spectrum.

The further study showed that single-sectional TSFEL amplifiers are characterized by a pronounced self-excitatory inclination due to an extremely high level of amplification. As shown in the works [1-2], a rather effective method for solving this problem is the use of schemes of the klystron type TSFEL. The main feature of this design is a very deep solution to the inputoutput. This leads to the complete elimination of the aforementioned inclination of one-section TSFEL to self-excitation. 


\section{Formulation of the problem}

The multiharmonic klystron type TSFEL, which uses rectilinear relativistic electron beams [1-3], was investigated. The use of helical two-flow electron beams in devices of this type was not considered. The preliminary analysis shows that such beams can be substantially increased as the coefficients of amplification of electromagnetic waves (this will reduce the longitudinal dimensions of such devices) and the width of the frequency spectrum of electromagnetic waves [6-8]. Therefore, this work is devoted to the study of multiharmonic processes in the flying section of the klystron TSFEL with helical two-current relativistic electron beams. In the cubic-nonlinear analysis it was found that the use of helical two-stream beams in TSFEL allows forming waves with a wide frequency spectrum more efficiently.

\section{TSFEL-Klystron model}

The simplest version of the klystron type TSFEL amplifier scheme is shown in Fig. 1.

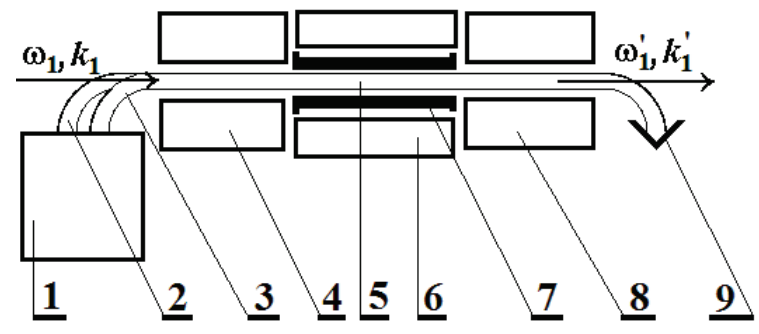

Fig. 1. Model of the klystron type TSFEL-amplifier

The device works as follows. The bifurcated accelerator 1 generates two mono-speed propellant relativistic electron beams 2 and 3, respectively. Both of these beams are fed to the input of the first pump system 4 . After that, they form a combined two-stream helical electron beam 5 . Electromagnetic signal $\omega_{1}, k_{1}$ (in the form of an amplified electromagnetic wave) is fed to the same input of the first pump system 4. In system 4, the modulation of a two-speed electron beam at density is the result of nonlinear parametric interactions of an electromagnetic wave $\omega_{1}, k_{1}$, the first pump system 4 . In the modulated electron beam 5 , which moves in the flight section 6 , the wave of spatial charge is excited by frequency $\omega_{3}$ ( frequencies $\omega_{1}$ and $\omega_{3}$, in general, may be different). This means that the initial (input) signal $\omega_{1}, k_{1}$ transformed from an electromagnetic form into an electron-wave in the first pump system.
The two-stream instability develops in the electron beam 5 in the flight section 6 . We note that the maximum amplification of longitudinal electron waves due to two-stroke instability takes place for the waves of the SCW, which are characterized by optimal frequency $\omega_{\text {opt }}$ [1-7]. The key point of the design discussed in this paper is that the modulation frequency $\omega_{3}$ is much smaller than the optimal frequency $\omega_{\text {opt }}$. In this case, as it will be shown below, there is an intense generation of higher harmonics due to multiple three-wave parametric resonance interactions, and then their amplification due to two-flow instability. There is a formation of SCW with a wide frequency spectrum containing an abnormal area in which higher harmonics are characterized by larger amplitudes. Thus, the input signal $\omega_{1}, k_{1} \mathrm{c}$ exists in the flight section 6 in the form of multiharmonic electronic waves of spatial charge. It should be noted that in the flight section 6 , the electromagnetic signal (input) $\omega_{1}, k_{1}$ is absent due to the absorption by its absorber 7. Next, the modulated electron beam with a multiharmonical SCW enters the second pump system 8. Here the output electromagnetic signal is generated $\omega_{1}^{\prime}, k_{1}^{\prime}$. This is due to the nonlinear interaction of the modulated electron beam 5 with the field of the second pump system 8 . This means that the inverse transformation of the electron-wave form of the signal $\omega_{3}, k_{3}$ into the electromagnetic form $\omega_{1}^{\prime}, k_{1}^{\prime}$ in the working volume of the second pump system 8 occurs. The spent electron beam is further absorbed by the collector 9 . Thus, at the output of the klystron type TSFEL we obtain a powerful multi-harmonic electromagnetic signal with a wide frequency spectrum. It should be noted that the formation of a multiharmonic electromagnetic signal occurs due to the use of a multihomonic wave of spatial charge in the pump section 8 .

The presented work is devoted to the investigation of multiple resonance interactions of the harmonics of a growing SCW in the flight section 6 of the the klystron type two-flow laser on free electrons with a helical electron beam. We consider the following model of a twoflow helical electron beam in the flight section 6 . The helical beam contains two partially interpenetrating electronic streams with close relativistic velocities $v_{1}, v_{2}\left(v_{1}-v_{2}<<v_{1}, v_{2}\right)$. The beam moves at an angle $\alpha$ to the focusing magnetic field $\mathbf{B}_{0}$ along the helical trajectory. Plasma frequencies of partial beams are taken equal $\omega_{\mathrm{p} 1}=\omega_{\mathrm{p} 2}=\omega_{\mathrm{p}}$, we consider the spatial charge of the beam to be compensated by an ion background. 
The electric field of the SCW, which determines the dynamics of the two-flow instability, is considered multiharmonical:

$$
E_{\mathrm{z}}=\sum_{m=1}^{N}\left[E_{m} \exp \left(\mathrm{i}_{m}\right)+c . c .\right]^{\prime}
$$

where $N$ - the number of harmonics that we take into account for solving the problem; $p_{m}=\omega_{m} t-k_{m} z-$ phase, $\omega_{m}=m \cdot \omega_{1}-$ frequency of $m$ harmonic of $\mathrm{KhPZ}, k_{m}-$ its wave number, axis $Z$ is directed along the focusing magnetic field $\mathbf{B}_{0}$.

For the theoretical analysis of multiple resonance interactions in the flight section of the TSFEL with a helical electron beam, we use the quasi-hydrodynamic equation $[1,3,9]$, the continuity equation and the Maxwell equation. Apply a hierarchical approach to the theory of oscillations and waves $[1,3]$. As a result, we obtain a cubic nonlinear system $m$ of differential equations for the complex amplitudes of the harmonics of the electric field strength of the SCW:

$$
\begin{gathered}
C_{2, m} \frac{d^{2} E_{m}}{d z^{2}}+C_{1, m} \frac{d E_{m}}{d z}+D_{m} E_{m}= \\
=C_{3, m}\left\langle E_{z} \cdot \sum_{m^{\prime}=1}^{N}\left[E_{m^{\prime}} \exp \left(\mathrm{i}_{m^{\prime}}\right) /\left(\mathrm{i} m^{\prime}\right)+c . c .\right]\right\rangle_{p_{m}}+F_{m}
\end{gathered}
$$

where

$$
D_{m}\left(\omega_{m}, k_{m}\right) \equiv-\mathrm{i} k_{m}\left(1-\sum_{q=1}^{2} \frac{\omega_{\mathrm{p}}^{2}\left(1-\left(\mathrm{v}_{q z} / c\right)^{2}\right)}{\left(\omega_{m}-k_{m} \mathrm{v}_{q z}\right)^{2} \gamma_{q}}\right)
$$

$C_{1, m}=\partial D_{m} / \partial\left(-i k_{m}\right), \quad C_{2, m}=\partial^{2} D_{m} / \partial\left(-i k_{m}\right)^{2} / 2$, $<\ldots>_{p_{m}}=\frac{1}{2 \pi} \int_{0}^{2 \pi}\left(\ldots \cdot \exp \left(-\mathrm{i} p_{m}\right)\right) d p_{m}, \quad F_{m}-$ functions that take into account cubic-nonlinear terms, which, among others, are related to multiple parametric resonance interactions in the system under the study.

\section{Analysis}

We choose the parameters of the system so that the conditions for two-stroke instability [1-7,9] are fulfilled. In this case, the dispersion equation for the SCW in a helical two-flow electron beam is as follows:

$$
\begin{gathered}
D_{m}\left(\omega_{m}, k_{m}\right) \equiv \\
\equiv-\mathrm{i} k_{m}\left(1-\sum_{q=1}^{2} \frac{\omega_{\mathrm{p}}^{2}\left(1-\left(\mathrm{v}_{q z} / c\right)^{2}\right)}{\left(\omega_{m}-k_{m} v_{q z}\right)^{2} \gamma_{q}}\right)=0
\end{gathered}
$$

lytic solution of equation (4) for a helical relativistic two-flow electron beam can be found in the same way as for the case of a rectilinear beam (see, for example, [1]). The solution is found by:

$$
k_{m}=\omega_{m} / \mathrm{v}_{0 z}+\mathrm{i} \Gamma_{m}
$$

where $v_{0 z}=\left(v_{1 z}+v_{2 z}\right) / 2, i \Gamma_{m}-$ nonlinear imaginary additive to the wave number of the SCW. Substituting (5) into (4), we carry out simple algebraic transformations and find an approximate formula for this additive:

$$
\begin{gathered}
i \Gamma_{m} \approx \pm \frac{\omega_{p} \sqrt{1-\left(\mathrm{v}_{0 z} / c\right)^{2}}}{\gamma_{0} \mathrm{v}_{0 z}} \times \\
\times\left\{1+\frac{\omega_{m}^{2} \delta^{2} \gamma_{0}}{\omega_{p}^{2} \sqrt{1-\left(\mathrm{v}_{0 z} / c\right)^{2}}} \pm \sqrt{1+\frac{4 \omega_{m}^{2} \delta^{2} \gamma_{0}}{\omega_{p}^{2} \sqrt{1-\left(\mathrm{v}_{0 z} / c\right)^{2}}}}\right\}^{1 / 2} .(6) \\
\text { In } \quad \text { formula: } \quad(6) \quad \gamma_{0}=1 / \sqrt{1-\left(\mathrm{v}_{0} / c\right)^{2}}, \\
\mathrm{v}_{0}=\left(\mathrm{v}_{1}+\mathrm{v}_{2}\right) / 2, \delta=\left(\mathrm{v}_{1}-\mathrm{v}_{2}\right) /\left(\mathrm{v}_{1}+\mathrm{v}_{2}\right) .
\end{gathered}
$$

From the relation (6) it follows that if the frequency of the harmonica of the SCW $\omega_{m}$ is less than the critical frequency of the two-flow instability in the helical two-stream electron beam:

$$
\begin{aligned}
& \omega_{\mathrm{cr}}=\frac{\sqrt{2} \omega_{p}}{\delta} \sqrt{\frac{1-\left(\mathrm{v}_{0 z} / c\right)^{2}}{\gamma_{0}}}= \\
& =\frac{\sqrt{2} \omega_{p}}{\delta} \sqrt{\frac{1-\left(\mathrm{v}_{0} \cos (\alpha) / c\right)^{2}}{\gamma_{0}}}
\end{aligned}
$$

then the two waves will be characterized by an integrated wave number $k$ (in the ratio (7) used that $v_{0 z}=v_{0} \cos \alpha$ ). One of these waves will exponentially grow (increasing wave). For it, the value $\Gamma_{m}$ (6) has the physical meaning of incremental growth $m$-th harmonic of SCW. Another wave will exponentially dampen (extinction wave). Due to the fact that the amplitude of the extinction wave will decrease rapidly, then this wave will not be considered further. It is not difficult, analyzing (6), to find the optimal frequency for a helical two-flow electron beam:

$$
\omega_{\mathrm{opt}}=\frac{\sqrt{3} \omega_{p}}{2 \delta} \sqrt{\frac{1-\left(\mathrm{v}_{0 z} / c\right)^{2}}{\gamma_{0}}}=\omega_{\mathrm{cr}} \sqrt{\frac{3}{8}}
$$

which corresponds to the maximum incremental growth: 


$$
\begin{gathered}
\Gamma\left(\omega_{\mathrm{opt}}\right)=\frac{\omega_{p}}{2 \mathrm{v}_{0 z}} \sqrt{\frac{1-\left(\mathrm{v}_{0 z} / c\right)^{2}}{\gamma_{0}}}= \\
=\frac{\omega_{p}}{2 \mathrm{v}_{0 z}} \sqrt{\frac{1-\left(\mathrm{v}_{0} \cos \alpha / c\right)^{2}}{\gamma_{0}}}
\end{gathered}
$$

Analyzing formulas (7) - (9), we can verify that when the angle of flight of the electron beam $\alpha$ increases, both the critical frequency (7) and the maximum increment of growth (9) increase too. Thus, the development of two-flow instability in helical two-flow electron beams occurs with higher growth increments than in straight-line beams. Therefore, the use of helical beams in two-stream superheterodyne lasers on free electrons leads to an increase in the rates of amplification of electromagnetic waves. From the above analysis it follows that such an increase in the rate of amplification of an electromagnetic signal in two-current SLVE is associated with an increase in the increment of twocurrent instability in helical relativistic electron beams. It should also be noted that for helical electron beams, both the optimal frequency of two-stroke instability and the critical frequency are higher compared to straightline electron beams. This means that two-current SLVEs with helical electron beams can operate at higher frequencies than SLVEs using rectilinear beams.

From equation (5) it also follows that in a helical two-stream electron beam for harmonics of a SCW whose frequencies are less than the critical frequency $\omega<\omega_{\text {cr }}$ will be implemented by multiple three-wave parametric resonances [1, 3-5]. The emergence of multiple parametric resonances is due to the fact that, as follows from the relation (5), for a growing wave, the relation between the real part of the wave number and the frequency is linear:

$$
\operatorname{Re}(k)=\omega / \mathrm{v}_{0 z}
$$

This means, that if for $m$ harmonica frequency will be $\omega_{m}=m \cdot \omega_{1}$ or in $m$ times greater than the frequency of the first harmonica $\omega_{1}$, then the real part of the wave number of $m$ harmonica $\operatorname{Re}\left(k_{m}\right)$ will also be in $m$ times more than the actual part of the wave number of the first harmonic $\operatorname{Re}\left(k_{1}\right)$ (in case $\omega_{m}<\omega_{\text {cr }}$ ):

$$
\operatorname{Re}\left(k_{m}\right)=\omega_{m} / \mathrm{v}_{0 z}=m \omega_{1} / \mathrm{v}_{0 z}=m \operatorname{Re}\left(k_{1}\right)
$$

Thus, the phase of $m$ harmonica (it is determined by the real part of the wave number):

$$
\begin{gathered}
p_{m}=\omega_{m} t-\operatorname{Re}\left(k_{m}\right) z= \\
=m \cdot \omega_{1} t-m \cdot \operatorname{Re}\left(k_{1}\right) z=m \cdot p_{1}
\end{gathered}
$$

will be $m$ times greater than the phase of the first har- monica. This leads to the fact that in a two-flow system for a large number of harmonics of the $\mathrm{KhPZ}$, which satisfy the condition $\omega<\omega_{\mathrm{cr}}$, the conditions of the three-wave parametric resonance will be fulfilled:

$$
p_{m_{1}}=p_{m_{2}}+p_{m_{3}} \text { aбо } m_{1}=m_{2}+m_{3},
$$

where $m_{1}, m_{2}, m_{3}$ - are integers. The condition (12) is realized with the participation of a huge number of harmonics, for example, $5=2+3,5=7-2,5=9-4,4=2+2$ and so on. Therefore, we are talking about the situation created as the one in which multiple parametric threewave resonances are implemented.

Thus, due to the linear dispersion dependence on condition $\omega<\omega_{\mathrm{cr}}$ multiple parametric resonances between the harmonics of the SCW are realized in the system. As a result of the enormous amount of three-wave parametric resonance interactions, the formation of an SCW with a wide multiharmonic spectrum occurs in which higher harmonics have higher amplitudes than lower harmonics.

Another feature of the formation of a SCW with a wide multiharmonic spectrum in helical two-flow electron beams is that, in accordance with (7), the critical frequency for helical beams increases with the increase of the angle of flight $\alpha$ of the electron beam. This means that the frequency region in which the formation of the multiharmonic spectrum occurs is increasing. This fact is illustrated in Fig. 2, which depicts the growth rates of two-stroke instability growth for different angles of flight $\alpha$. These dependences are obtained by numerical solution of equation (4).

Consider the case: $\omega_{p 1}=\omega_{p 2}=\omega_{p}=1,5 \cdot 10^{11} \mathrm{c}^{-1}$, $\gamma_{1}=4,8, \gamma_{2}=4,2$. Curve 1 corresponds to the case $\alpha=0^{\circ}$, curve 2 - case $\alpha=10^{\circ}$, curve 3 - case $\alpha=20^{\circ}$, curve $4-$ case $\alpha=30^{\circ}$. Frequency of the first harmonic $\omega_{1}=0,6 \cdot 10^{12} \mathrm{c}^{-1}$. From Fig. 2 follows the conclusions obtained from the analysis of the relations (7) - (9): with increasing the angle of flight of the two-stream beam, both the increments $\Gamma$, and critical frequency $\omega_{\mathrm{cr}}$ are increased. 


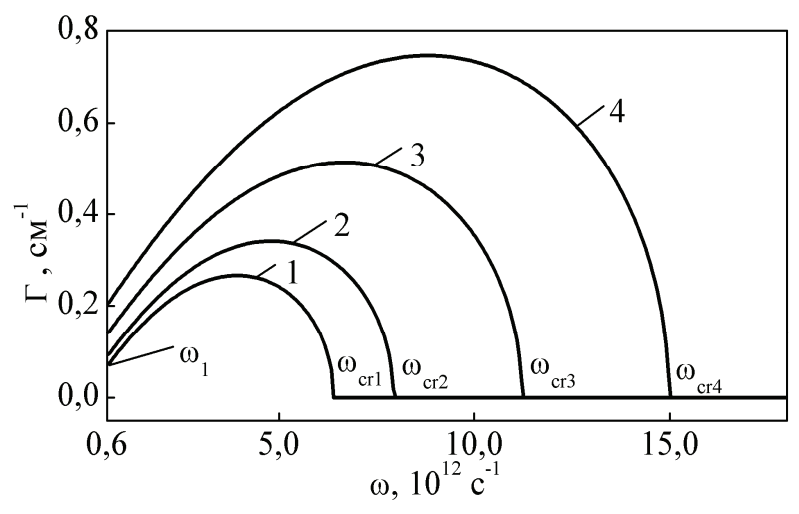

Fig. 2. Incidence of two-stroke instability growth for different angles $\alpha$. Curve 1 corresponds to the case $\alpha=0^{\circ}$, curve 2 case $\alpha=10^{\circ}$, curve 3 - case $\alpha=20^{\circ}$, curve 4 - case $\alpha=30^{\circ}$.

When the frequency of the first harmonic of the $\mathrm{KhPZ} \omega_{1}$ will be much less than the critical frequency, the multiple parametric resonances between the harmonics of the refractometer will occur in the frequency region $\omega_{1}<\omega_{m}<\omega_{\text {cr }}$. From Fig. 2 it follows that for helical two-stream beams with an increase in the angle of flight of the beam $\alpha$ this area will increase. It means that the use of helical two-flow electron beams is more appropriate in multiharmonic LVEs the main task of which is to form a powerful electromagnetic signal with a wide frequency spectrum $[1,3]$.

In Fig. 3 the dependences of amplitudes of the electric field strength of ten harmonics of the SCW from the longitudinal coordinate $z$ for the angle of flight of the electron beam $\alpha=0^{\circ}$ (curves 1) i $\alpha=20^{\circ}$ (curves 2). The parameters used to calculate are the same as for Fig. 2 At the entrance of the investigated system in both cases, the SCW was monochromatic with a frequency of $\omega_{1}=0,6 \cdot 10^{12} \mathrm{c}^{-1}$, that is, it consisted of one harmonic. The calculation of dependencies was carried out using the system of equations for the amplitudes of the harmonics of the electric field tension (3).

From Fig. 3 it follows that the rates of amplification of harmonics of the electric field strength for a helical electron beam (curve 2) are higher than for a straightline electron beam (curve 1), that confirms the above analysis. It also follows from Fig. 3 that due to the multiple three-wavelength parametric resonances, higher harmonics are excited, and then amplified due to twostream instability. As a result of such processes a high frequency spectrum SCW is formed. Note that with the increase in the number of harmonics, the increments of their growth increase up to optimal frequency (Fig. 2), therefore the rate of amplification of higher harmonics appears to be higher. That is why an abnormal section of the spectrum is formed, in which higher harmonics have higher amplitudes. It should also be noted that the levels of saturation of the harmonics of SCW in the case of a helical electron beam (curves 2) are higher than for a straight-line beam (curves 1). The saturation lengths for the harmonics of the KhPZ (curve 2) in the helical two-stream electron beam are smaller than the straight-line beam (curve 1), $z_{\mathrm{st} 2}<z_{\text {st1 }}$. Thus, the flown section of a two-flow LWEE using helical electron beams, due to higher rates of gain, will have smaller longitudinal dimensions than two-current SLWEs using rectilinear electron beams.

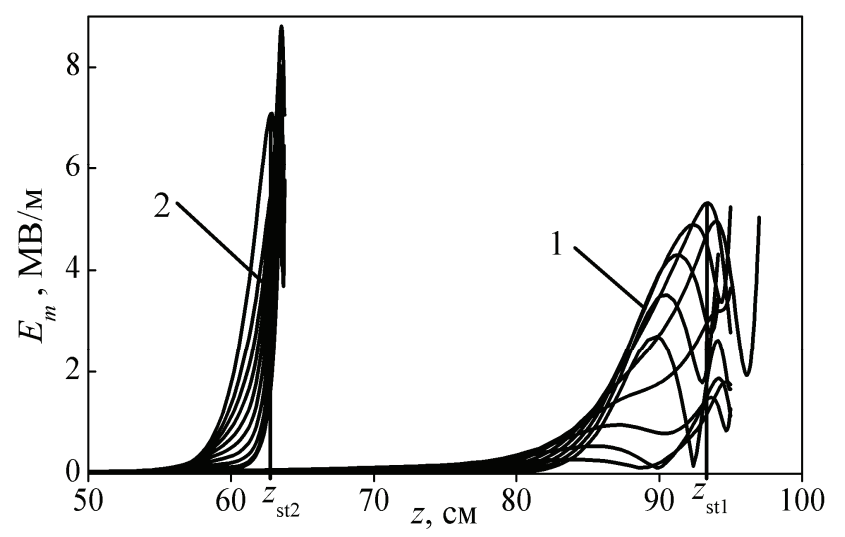

Fig. 3 Dependences of the amplitudes of the electric field strength of the harmonics of the SCW on the longitudinal coordinate $\mathrm{z}$ for the angle of flight of the electron beam $\alpha=0$ ${ }^{\circ}$ (curves 1) and $\alpha=20^{\circ}$ (curves 2)

\section{Conclusions}

In the present work, the cubic nonlinear theory of multiple resonance interactions of the harmonics of the growing wave of spatial charge in a two-flow helical electron beam propagating in the flight section of the klystron type TSFEL has been constructed.

It is shown that the increment of growth of refinery in a helical two-stream electron beam is significantly higher than in a rectilinear beam. This means that twostream superheterodyne LVEs that use two-stream instability in helical electron beams as an additional mechanism for amplifying electromagnetic waves will have higher amplification rates compared to TSFEL using rectilinear electron beams. It was found that the levels of saturation for SCW in the flywheel section of TSFEL with a helical electron beam are higher than for a straight-line beam. It has also been shown that the saturation lengths in the case of a helical electron beam are smaller. From this it follows that the use of helical two-flow electron beams in TSFEL results in both increased levels of saturation and the reduction of longi- 
tudinal dimensions.

It is demonstrated that in the propellant two-flow electron beam, due to the linearity of the dispersion characteristic of a growing $\mathrm{SCW}$, the condition of a three-wave parametric resonance is fulfilled for all harmonics, the frequency of which is less than the critical frequency of two-flow instability. That's why for multiharmonic operation, the modulation section should be configured to excite the first harmonic of the SCW with the frequency much lower than the critical frequency. Then, in the flight section, due to the large number of three-wave parametric resonances, an intense generation of higher harmonics of the SCW will take place. The subsequent amplification of such harmonics will occur both at the expense of parametric amplification, and due to two-current instability. As a result, there is an excitation of a large number of higher harmonics with almost identical amplitudes, and SCW with a wide frequency spectrum is formed. It is found that the width of such a frequency spectrum increases with the increase of the angle of flight $\alpha$ of a two-flow electron beam (Fig. 2). This is due to an increase in the critical frequency $\omega_{\mathrm{cr}}$ in helical electron beams compared with straight beams.

Thus, due to multiple parametric resonances, a powerful multi-harmonic pulse with a wide frequency spectrum is formed in the flight section of the klystron type TSFEL with a helical electron beam. Such a multigarmion wave, falling into the final section, becomes a powerful source of a multiharmonic electromagnetic signal. Therefore, the use of helical electron beams in multiharmonic TSFEL leads to an increase in their amplification characteristics, the frequency spectrum width in the mode of generation of the multiharmonic signal, as well as the reduction of the dimensions compared with TSFEL, which use rectilinear beams.

Thus, TSFEL with helical electron beams is a new rather promising class of devices for generating a powerful multi-harmonic signal with a wide frequency spectrum in millimeter-infrared wavelength ranges.

\section{References}

1. Kulish V. V. Hierarchic electrodynamics and free electron lasers: concepts, calculations, and practical applications. - CRC Press, 2011. - 700 p.

2. Kulish V. V. On the theory of superheterodyne lasers on the klystron type free electrons // Ukr. phys. journal 1991.36. - No. 1. - P. 28-33.

3 . Hierarchical asymptotic methods in the theory of cluster free electron lasers / V. V. Kulish, A. V. Lysenko, A. J. Brusnik // Journal of Infrared, Millimeter, and Terahertz Waves. - 2012. - Vol. 33, No. 2. - P. 149-173.

4. Effect of parametric resonance on the formation of waves with a broad multiharmonic spectrum during the development of two-stream instability / V. V. Kulish, A. V. Lysenko, M. Y. Rombovsky // Plasma Physics Reports. 2010. - Vol. 36, No. 7. - P. 594-600.

5. Plural interactions of space charge wave harmonics during the development of two-stream instability / V. V. Kulish, A. V. Lysenko, M. Y. Rombovsky, V. V. Koval, I. I. Volk // Chinese Physics B. - 2015. — Vol. 24, No. 9. — P. 095201.

6. Mahdizadeh N. Saturation mechanism in a two-stream free-electron laser // Journal of Plasma Physics. — 2015. Vol. 81, No. 06.

7. Instability of wave modes in a two-stream free-electron laser with a helical wiggler and an axial magnetic field / T. Mohsenpour, N. Mehrabi // Physics of Plasmas (1994present). — 2013. - Vol. 20, No. 8. - P. 082133.

8. Superheterodyne plasma-beam lasers with helical electron beams / V.V. Kulish, A.V. Lysenko, G.A. Alekseenko, V.V. Koval, M. Yu. Rombovskii // Applied Physics. - 2014. - No. 5. - P. 24-28.

9. Ng K.-Y. Physics of intensity dependent beam instabilities. — World Scientific, 2006.

Received in final form on November 25, 2017 
Лисенко О.В., Волк Ю.Ю., Серьожко А.С., Рибалко О.О.

Множинні трихвильові резонанси в двопотоковому ЛВЕ-клістроні із гвинтовим електронним пучком

Проблематика. Створення джерел потужного терагерцового випромінювання є одним з перспективних напрямків розвитку релятивістської плазмової електроніки. На цей час пристроїв, які здатні створювати потужне випромінювання в міліметровому - інфрачервоному діапазоні (навіть у частині цього діапазону), є досить мало. Тому теоретичні дослідження нових джерел потужного терагерцового випромінювання, які також характеризуються широким частотним спектром є задачею актуальною.

Мета досліджень. Вивчення впливу множинних трихвильових резонансних взаємодій у двопотоковому супергетеродинному лазері на вільних електронах (ДСЛВЕ) клістронного типу з гвинтовими електронними пучками на ефективність формування потужних хвиль 3 широким частотним спектром.

Методика реалізації. Для теоретичного аналізу множинних резонансів гармонік хвиль як вихідні використовуємо квазігідродинамічне рівняння, рівняння неперервності й рівняння Максвелла. До рівнянь руху та неперервності застосовуємо ієрархічний підхід у теорії коливань і хвиль, до рівнянь Максвела - метод повільно змінних амплітуд. У підсумку отримуємо кубічну нелінійну систему диференціальних рівнянь для комплексних амплітуд гармонік напруженості електричного поля, яку досліджуємо стандартними методами.

Результати досліджень. Показано, що в двопотокових супергетеродинних ЛВЕ, які використовують двопотокову нестійкість у гвинтових електронних пучках як додатковий механізм підсилення електромагнітних хвиль, завдяки множинним резонасним взаємодіям формується потужна мультигармонічна хвиля просторового заряду із широким частотним спектром. Ширина спектру такої хвилі є більшою порівняно з шириною спектра у ДСЛВЕ, які використовують прямолінійні електронні пучки. Також з'ясовано, що темпи підсилення хвиль у таких ДСЛВЕ є більшими.

Висновки. Застосування гвинтових електронних пучків у мультигармонічних ДСЛВЕ, які використовують множинні резонансні взаємодії, призводить до збільшення їх підсилювальних характеристик, ширини частотного спектра в режимі генерації мультигармонічного сигналу, а також зменшення габаритів порівняно із ДСЛВЕ, які використовують прямолінійні пучки.

Ключові слова: двопотокові супергетеродинні лазери на вільних електронах; двопотокова нестійкість; гвинтові електронні пучки, трихвильові резонанси.

Лысенко А.В., Волк Ю.Ю., Серёжко А.С., Рыбалко А.А.

Множественные трёхволновые резонансы в двухпотоковом ЛСЭ-клистроне с винтовым электронным пучком

Проблематика. Создание источников мощного терагерцового излучения является одним из перспективных направлений развития релятивистской плазменной электроники. На данный момент устройств, способных создавать мощное излучение в миллиметровом-инфракрасном диапазоне (даже в части данного диапазона), существует достаточно мало. Поэтому, теоретические исследования новых источников мощного терагерцового излучения, характеризующихся также широким частотным спектром, являются задачей актуальной.

Цель исследований. Изучение влияния множественных трёхволновых резонансных взаимодействий в двухпотоковом супергетеродинном лазере на свободных электронах (ДСЛСЭ) клистронного типа с винтовыми электронными пучками на эффективность формирования мощных волн с широким частотным спектром.

Методика реализации. Для теоретического анализа множественных резонансов гармоник волн в качестве исходных используем квазигидродинамическое уравнение, уравнение непрерывности и уравнения Максвелла. К уравнениям движения и непрерывности применяем иерархический подход к теории колебаний и волн, к уравнениям Максвелла - метод медленно меняющихся амплитуд. В результате получаем кубическую нелинейную систему дифференциальных уравнений для комплексных амплитуд гармоник напряженности электричесокго поля волны пространственного заряда, которую изучаем стандартными методами.

Результаты исследований. Показано, что в двухпотоковых супергетеродинных ЛСЭ, использующих двухпотоковую неустойчивость в винтовых электронных пучках в качестве дополнительного механизма усиления электромагнитных волн, благодаря множественным резонансным взаимодействиям формируется мощная мультигармоническая волна пространственного заряда с широким частотным спектром. Ширина спектра такой волны является большей по сравнению с шириной спектра в ДСЛСЭ, использующих прямолинейные электронные пучки. Также выяснено, что темпы усиления в таких ДСЛСЭ являются большими.

Выводы. Применение винтовых электронных пучков в мультигармонических ДСЛСЭ, использующих множественные резонансные взаимодействия, приводит к увеличению их усилительных характеристик, ширины частотного спектра в режиме генерации мультигармонического сигнала, а также уменьшению габаритов по сравнению с ДСЛСЭ, использующими прямолинейные пучки.

Ключевые слова: двухпотоковые супергетеродинные лазеры на свободных электронах; двухпотоковая неустойчивость; винтовые электронные пучки; трёхволновые резонансы 